総説

\title{
ビタミンEの栄養状態に及ぼす食事性因子の影響十
}

\author{
五十嵐脩 \\ 怙莱の水女子大学生活環境研究センター
}

\author{
Dietary Factors Affecting Vitamin E Status \\ Osamu IGARASHI \\ Institute of Environmental Science for Human Life, Ochanomizu University, \\ 2-1-1, Ohtsuka, Bunkyo-ku, Tokyo 112
}

\begin{abstract}
ビタミンEは脂溶性ビタミンの一つで, 天然には八つ の同族体が存在する。ピタミン Eは 2 位の側鎖の 2 重結 合の有繁によりトコフェロール類とトコトリェノール類 に大きく分けられる。それら同族体の生理活性はこれま で一般的には $\alpha$-トコフェロールを 100 とすると， $\beta$-ト

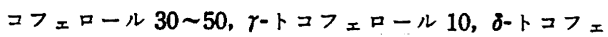
ロール3以下とされている1。 またトコトリェノール については $\alpha$-トコトリェノールが米国の 栄養所要量の 算定に祭して 50 とされているのを除けば，他のトコト リェノールについてはデータがほとんどない22。なお，
\end{abstract} 平成元年に公表された日本食品標準成分表の脂溶性成分 のフォローフップ゙ では脂溶性ビタミン研究委員会に設 けられた小委員会の報告( 飞基ついて， $\alpha$-トコフェロー ル 100 としたときに $\beta$-トコフェロール25, $\gamma$-トコフェ ロール5, カトンフェロール0.1としている。このフォ ローフップで公表されたトコフェロール同族体の各種食 品での含量と各同族体の生理活性値を勘案すると，食事 由来の最む重要なビタミンEは $\alpha$ トレコフロールで, 次 いで $\gamma$ トコフェロールのニつであることがわかる。その 他のビタミンEは撕取量, 生物活性值の両方から考え, ビタミンEとしての重要性はほとんどないと考えてよい であろう。事実, 人の血清中あるいは組織中で検出され

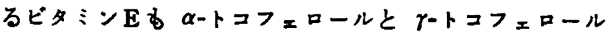
の二つであり，その䈨度す約 $90 \%$ を $\alpha$ トコフェロール

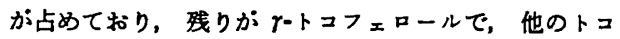
フェロールはまったく検出されないといってよい。した

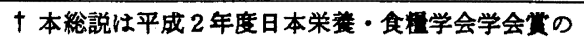
対象となったるののうち，栄䴬閶係についてをと めたすのである。

干112 東京都文京区大坲 2-1-1
がって, 栄橆的点からは $\alpha$-トコフェロールがビタミン $\mathrm{E}$ の中心的位置を占めており，本総説でもビタミン しては $\alpha$-トコフェロールを中心において述べることに する。

ピタミンEの発見のきっかけは抗不妊作用であった が，発見当初よりビタミン $\mathrm{E}$ の抗酸化剂としての作用か 注目されてきた。そして，ビタミンE久乏の進行には同 時に摄取している脂肪の不飽和度が大きく影響すること が知られていた5)。つまり, Fig. 1 に示すよらにラット に不飽和度の異なる脂肪酸を投与すると, 飽和脂肪酸の エステルを恸取している動物に比へて, 二重結合を二つ るつリノール酸のエステル,三つの $\alpha$-リノレン酸のエス テル，あるいはより不飽和度の高い脂肪酸エステルを掑 取している動物のほうが久乏を起しやすく二重結合の数 が多いほどより早くビタミンE欠乏になりやすいといっ た事実である。なお，この実験では尿中のクレフチン/ クレアチニン比を測定し筋ジストロフィーの進行を指標 としている。このよらな関係は早くから油脂の酸化時に おいても観察されていた現象であり，ビタミン Eが生体 内です抗酸化剂として機能していることを示㖫している

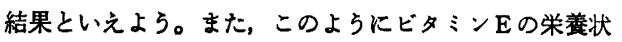

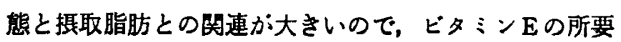
基の策定には食事中の脂肪の多価不飽和脂肪酸の摄取比 る考成されている。以下, 本総説ではビタミン $\mathrm{E}$ の栄㛐 状態に影要する因子として摄取油脂，タンバク質，他の ビタミンなどの影零，同じビタミン $\mathrm{E}$ 同族体間の相互作 用などについてわれわれの研究結果を中心において述へ てみたい。 


\section{1. 掫取油脂とビタミンEの栄算状態}

前述のように，摄取油脂の不飽和度により，ビタミン E欠乏状態の進行が影敏されることは以前から知られて いたが，実際に組織中のビタミン E 湍度がどのよらに影 整されるかについてはそれはど多くの報告がある訳では ない。われわれは魚油の研究の一環としてタラ肝油およ びイワシ油を投与したときの血液中の脂質,過酸化脂質,

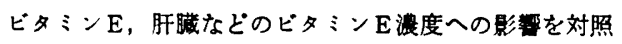
として植物油のコーン油を用いて検討した。また，タラ 肝油とコーン油との混合比率を $0: 100,25: 75,50$ : 50, $75: 25,100: 0$ とし, イワシ油では $0: 100$ から $50: 50$ まで変化させて,ビタミン $\mathrm{E}$ 久乏進行への魚油摂 取の影橰を検討した6)。なお，ここではビタミンEを中 心にして述べるが, 結果は Table 1, Table 2 に示すよ らにビタミンE久乏の進行に伴い，血清，肝薾中の $\alpha$ トコフェロール潢度はタラ肝油あるいはイワシ油の混合 比率の上昇に伴い，著しく低下した。なお，血清の脂質 レヘンルもビタミン $\mathrm{E}$ 同様に, 魚油投与レベルの上昇に伴 い, 有意に低下していることも観察している。この実験 に際し，われわれは油脂から効率よくビタミン E, とく

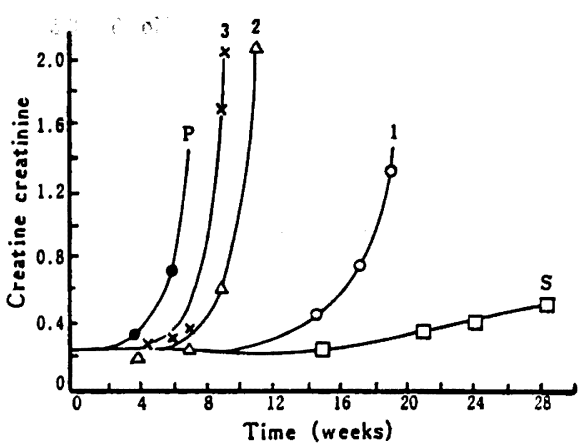

Fig. 1. Relative rates of increase in creatine/ creatinine ratio in urine of tocopheroldepleted rats fed fats formulated to be saturated (S), monoene (1), diene (2), triene (3), and polyenic (P).

に $\alpha$ ートコフェロールを除去する万法も開発している7。 類似した結果は觙らすラットに $10 \%$ レペルでラード, オリーブ油、サフラワー油, アマニ油, イワシ油を投与 した際に, 肝臓の $\alpha$-トコフェロール港度が油脂の不飽和

Table 1. Effect of cod liver oil intake upon concentrations of serum and liver $\alpha$-tocopherol and TBA value of liver of rats (Exp. 1).

\begin{tabular}{lcccc}
\hline \hline & \multirow{2}{*}{\begin{tabular}{c} 
Serum $\begin{array}{c}\alpha \text {-tocopherol } \\
(\mu \mathrm{g} / \mathrm{dl})\end{array}$ \\
\cline { 3 - 4 }
\end{tabular}} & \multicolumn{2}{c}{ Liver } \\
\hline $100 \%$ Corn & $274.6 \pm 35.2(100 \%)$ & $16.4 \pm 1.6(100 \%)$ & $73.3 \pm 19.2(100 \%)$ \\
$25 \%$ CLO & $223.5 \pm 50.9(81.4)$ & $15.1 \pm 1.2(92.1)$ & $65.4 \pm 13.3(-)$ \\
$50 \%$ CLO & $154.1 \pm 17.5(56.1)^{\mathrm{b}}$ & $11.0 \pm 1.3(67.1)^{\mathrm{b}}$ & $216.2 \pm 53.1(295)^{\mathrm{b}}$ \\
$75 \%$ CLO & $144.9 \pm 12.2(52.7)^{\mathrm{b}}$ & $10.5 \pm 1.0(64.0)^{\mathrm{b}}$ & $379.8 \pm 64.4(518)^{\mathrm{c}}$ \\
$100 \%$ CLO+V.E & $143.6 \pm 14.0(52.3)^{\mathrm{b}}$ & $8.6 \pm 1.0(52.4)^{\mathrm{b}}$ & $390.2 \pm 92.4(532)^{\mathrm{c}}$ \\
$100 \%$ CLO-V.E & $26.7 \pm 8.9(9.7)^{\mathrm{c}}$ & $1.9 \pm 0.4(11.5)^{\mathrm{c}}$ & $436.7 \pm 96.6(596)^{\mathrm{c}}$ \\
\hline \hline
\end{tabular}

Values are shown as mean $\pm S D$ of 6-8 animals. Values in parentheses are shown as percent for the $100 \%$ corn group. a Significantly different from the $100 \%$ corn group, $p<0.05$, b and $c$ also show the same degree of significance from the $100 \%$ corn group, but probabilities are $p<0.01$, and 0.001 , respectively.

Table 2. Effect of sardine-body oil intake upon levels of $\alpha$-tocopherol, lipid peroxidation and GOT activity in rat liver (Exp. 2).

\begin{tabular}{cccc}
\hline \hline & $\alpha$-Tocopherol $(\mu \mathrm{g} / \mathrm{g})$ & Lipid peroxidation (MDA nmol/g) & GOT activity (Karmen unit) \\
\hline $100 \%$ Corn & $13.9 \pm 1.7(100 \%)$ & $84.1 \pm 11.6(100 \%)$ & $34.6 \pm 16.7$ \\
$15 \%$ SBO & $12.2 \pm 1.7(87.8)$ & $143.8 \pm 22.6(171)^{\mathrm{b}}$ & $31.6 \pm 13.3$ \\
$25 \%$ SBO & $11.9 \pm 1.1(85.6)^{\mathrm{a}}$ & $187.0 \pm 27.8(222)^{\mathrm{b}}$ & $28.3 \pm 5.2$ \\
$50 \%$ SBO & $9.4 \pm 1.5(67.6)^{\mathrm{b}}$ & $305.6 \pm 63.8(363)^{\mathrm{c}}$ & $31.4 \pm 17.0$ \\
\hline \hline
\end{tabular}

Mean \pm SD. Values in parentheses are shown as percent for the $100 \%$ corn group. $a, b$ and $c$ see footnote of Table 1 . 
Table 3. The effects of diet protein level on $\alpha$-tocopherol concentration in RBC, serum, and tissue of rats.

\begin{tabular}{lcccccc}
\hline \multirow{2}{*}{ Group } & \multicolumn{2}{c}{ RBC } & & \multicolumn{2}{c}{ Serum } \\
\cline { 2 - 3 } \cline { 6 - 7 } & $\begin{array}{c}\alpha \text {-Toc } \\
(\mu \mathrm{g} / \mathrm{ml} \text { packed cell })\end{array}$ & $\begin{array}{c}\text { Free cholesterol } \\
(\mathrm{mg} / \mathrm{dl} \text { packed cell })\end{array}$ & & $\begin{array}{c}\alpha \text {-Toc } \\
(\mu \mathrm{g} / \mathrm{ml})\end{array}$ & $\begin{array}{c}\text { Total cholesterol } \\
(\mathrm{mg} / \mathrm{dl})\end{array}$ \\
\hline $20 \%$ Casein & $6.1 \pm 1.0^{*}$ & $105.2 \pm 4.2^{*}$ & & $6.8 \pm 0.8^{*}$ & $67.5 \pm 7.4$ \\
$10 \%$ Casein & $5.0 \pm 0.5^{\mathrm{a}}$ & $129.0 \pm 6.3^{\mathrm{a}}$ & & $6.7 \pm 0.7$ & $68.0 \pm 7.7$ \\
$20 \%$ SPI & $4.3 \pm 0.7^{\mathrm{a}}$ & $107.6 \pm 10.1$ & & $6.1 \pm 1.6$ & $65.3 \pm 7.8$ \\
\hline \hline
\end{tabular}

* Mean \pm SD. a Significantly different from $20 \%$ casein group $(p<0.05)$.

\begin{tabular}{ccccc}
\hline \hline Group & Liver* & Kidney* & Lung $^{*}$ & Muscle $^{*}$ \\
\hline $20 \%$ Casein & $40.0 \pm 8.5$ & $25.1 \pm 2.9$ & $45.2 \pm 4.8$ & $16.4 \pm 3.0$ \\
$10 \%$ Casein & $37.5 \pm 6.0$ & $21.4 \pm 6.0^{\mathrm{b}}$ & $35.2 \pm 4.6^{\mathrm{c}}$ & $13.5 \pm 0.8^{\mathrm{b}}$ \\
$20 \%$ SPI & $33.0 \pm 9.0^{\mathrm{b}}$ & $19.8 \pm 2.6^{\mathrm{b}}$ & $30.7 \pm 5.0^{\mathrm{c}}$ & $13.2 \pm 2.2^{\mathrm{b}}$ \\
\hline
\end{tabular}

* $\mu \mathrm{g} / \mathrm{g}$ fresh tissue. Mean $\pm \mathrm{SD}$. Values within column sharing a superscript letter differ significantly from $20 \%$ casein group (a $p<0.05, b p<0.01, c p<0.001)$.

度が高くなることで低下するという結果を得ている。な お，他の獸についてる同様な結果が得られている8)。

\section{2. 脂雷通䣹化物掫取とビタミン}

ビタミン Eが生体内抗酸化剈として機能していること

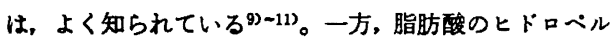
オキシドやその分解物であるケト酸などに代表される脂 質過酸化物性体に対し，毒性を有することが知られて いて，多数の報告がある(22-16)。また，ビタミンE投与が このような脂質過酸化物の毒性を軗减することす知られ ている。したがって，脂質過酸化物である脂肪酸のヒド ロベルオキシドや油脂の酸化物を少量連続的に投与する と，生体内でのビタミンEの消費が充進することが考え られる。われわれはこの点について，リノール酸ヒドロ ベルオキシドが in vitro の系では直接ビタミン $\mathrm{E}$ と反応 しないことを確かめだク上で，生体内でビタミンEや他 の抗酸化肪投与がリノール酸エチルのベルオキシドの連 続投与にどのような効果を示すのかを, 生体内過酸化脂 筫レペル，クルタチオンベルオキシダーセ（GSH-px）な どとの関連性から検討した ${ }^{18)}$ 。この結果, ビタミン $\mathrm{B}_{2}$ 四酪酸エステル，ブチルヒドロキシトルエン (BHT) 投 与群に比へ， $\alpha$-トコフェロール酢酸塩投与群でのみ, GSH-px の上昇が認められ，ビタミンEが脂筫過酸化物 投与に基つく毒性の発現に対し予防的に作用することを 見いだした。この点に関しては大気污染物質の一つであ る垔硫酸ガスを低䈨度でラットに吸わせたときや一時的 の高濃度で吸わせたときに観察される初期における $\alpha$ トコフェロールの肺脍への動員や $2 ， 3$ 日後に観察され
る GSH-px 活性の上㫒などと相通ずるむのといえよ $\zeta^{19220)}$ 。

\section{3. 摄取タンパク梊とビタミンEとの䦗係}

ビタミンEが血夜中を輸送される祭には、ビタミンA やDのように特定の結合タンバク質をもたないこともよ く知られている21)22)。しかし, 肝䁍や一部の葴器に $\alpha$-卜

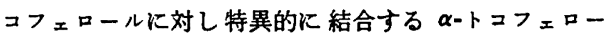
ル結合タンハク質が存在することが知られている237 -25)。 しかしこれらの細胞中に存在する $\alpha$ トコフェロール結 合タンハクク質の機能についてはいまた明確にされていな

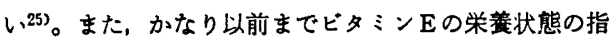
標として測定されてきた血清ビタミン $\mathrm{E}$ 值はきわめて悪 い栄装状態にある低開発国の児童では1日の間に大きく 変動することも観察されている28)。これらの結果は血中 のビタミンE值, すなわち $\alpha$ トコフェロールレベルが摄 取している食事中の栄嗂状態で変動されることを示唆す るものである。そのため, Horwitt らはビタミンEの栄 養状態の判定には血中の $\alpha$-トコフェロール（ビタミン E)/総脂質比の測定がビタミン $\mathrm{E}$ 栄粪状態の判定に望ま しいと述へている27)。一方，美湟らは多くの子供や成人 についてヒトの揚合，容易に採血できる細胞の代表とし て赤血球を取り上げ,赤血球中のビタミン $\mathrm{E}$ 値を測定し，

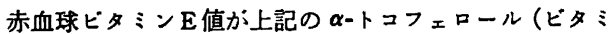
ンE)/総脂筫比とよく相関することを示した ${ }^{28) ~}{ }^{302}$ 。こ れらの結果については血小板のほらがより適切との意見

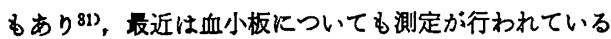
が，難点はヒトの場合血液がより多量に必要になる点に 
Table 4. The effects of protein levels on vitamin $E$ concentration in tissue of vitamin deficient rats and vitamin E-refed rats.

a) $\alpha$-Tocopherol levels in liver, kidney, lung, heart and muscle of vitamin E-deficient rats (Exp. 2).

\begin{tabular}{cccccc}
\hline \hline Group & Liver* & Kidney* & Lung* & Heart* & Muscle* $^{*}$ \\
\hline $40 \%$ Casein & $2.70 \pm 0.67$ & $3.98 \pm 0.17$ & $3.99 \pm 0.98$ & $5.39 \pm 0.35$ & $2.90 \pm 0.55$ \\
$20 \%$ Casein & $2.33 \pm 0.13$ & $2.91 \pm 0.02$ & $3.46 \pm 0.31^{\mathrm{b}}$ & $4.51 \pm 0.37 \mathrm{c}$ & $2.50 \pm 0.20$ \\
$10 \%$ Casein & $2.08 \pm 0.62$ & $2.44 \pm 0.43^{\mathrm{a}}$ & $2.69 \pm 0.63^{\mathrm{b}}$ & $4.13 \pm 0.53^{\mathrm{c}}$ & $2.39 \pm 0.48$ \\
\hline \hline
\end{tabular}

* $\mu \mathrm{g} / \mathrm{g}$ fresh tissue. Mean \pm SD. Values within column sharing a superscript letter differ significantly from $40 \%$ casein group (a $p<0.05, b p<0.01, c p<0.001$ ).

b) $\alpha$-Tocopherol levels in liver, kidney, lung, heart and muscle of vitamin E-refed rats (Exp. 2).

\begin{tabular}{cccccc} 
& & & \multicolumn{3}{c}{$(\mu \mathrm{g} / \mathrm{g}$ fresh weight $)$} \\
\hline \hline Group & Liver & Kidney & Lung & Heart & Muscle \\
\hline $40 \%$ Casein & $15.9 \pm 3.6^{*}$ & $7.49 \pm 0.66$ & $14.8 \pm 1.8$ & $11.3 \pm 1.8$ & $3.74 \pm 0.20$ \\
$20 \%$ Casein & $17.7 \pm 3.2$ & $6.18 \pm 0.40^{\mathrm{a}}$ & $12.7 \pm 1.3^{\mathrm{c}}$ & $10.7 \pm 1.3$ & $3.27 \pm 0.22^{\circ}$ \\
$10 \%$ Casein & $14.8 \pm 2.9$ & $4.20 \pm 0.50^{\mathrm{b}}$ & $12.3 \pm 1.3^{\mathrm{c}}$ & $\mathbf{8 . 7 5 \pm 0 . 8 \mathrm { d }}$ & $2.91 \pm 0.51^{\circ}$ \\
\hline \hline
\end{tabular}

* Mean $\pm S D$. a,c and o superscript letters mean a significant difference from $40 \%$ casein group (a $p<$ $0.001, c p<0.05$, $p<0.01$ ). $b$ and a superscript letters mean a significant difference from $20 \%$ and $40 \%$ casein groups (b $p<0.001$, d $p<0.05$ ).

c) $\alpha$-Tocopherol and free cholesterol levels in erythrocyte and $\alpha$-tocopherol and total lipids in serum of vitamin E-refed rats (Exp. 2).

\begin{tabular}{ccccccc}
\hline \multirow{2}{*}{ Group } & \multicolumn{2}{c}{ Erythrocyte } & & \multicolumn{2}{c}{ Serum } \\
\cline { 2 - 3 } \cline { 5 - 6 } & $(\mu \mathrm{g} / \mathrm{ml}$ packed cell $)$ & $\begin{array}{c}\text { Free cholesterol } \\
(\mathrm{mg} / \mathrm{dl} \text { packed cell })\end{array}$ & & $\begin{array}{c}\alpha \text {-Toc } \\
(\mu \mathrm{g} / \mathrm{ml})\end{array}$ & $\begin{array}{c}\text { Total lipids } \\
(\mathrm{mg} / \mathrm{dl})\end{array}$ \\
\hline $40 \%$ Casein & $2.99 \pm 0.46^{*}$ & $122 \pm 10$ & & $3.65 \pm 0.25$ & $135 \pm 1.5$ \\
$20 \%$ Casein & $3.15 \pm 0.24$ & $117 \pm 7.2$ & & $4.17 \pm 0.97$ & $131 \pm 22.0$ \\
$10 \%$ Casein & $2.83 \pm 0.40$ & $125 \pm 12$ & & $4.50 \pm 0.59 \mathrm{a}$ & $158 \pm 22.0^{\circ}$ \\
\hline \hline
\end{tabular}

* Mean \pm SD. a Significantly different from $40 \%$ casein group $(p<0.05)$. S Significantly different from $40 \%$ and $20 \%$ casein groups $(p<0.05)$.

$$
\text { ある。 }
$$

これらの結果はいずれにしても，ビタミンEの栄萑状 態には食事の栄養状態，脂省代謝の二つか関係すること を示唆するものである。われわれは、このなかでおすに

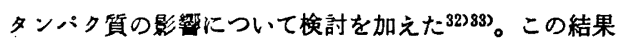
は大要 Table 3，4 にまとめられよ5。すなわち、ビタ ミンE投与レベルを同じにてひ，10，20，40\% とカセ インの摂取レペルを変化させること, また，同じタンパ ク質レヘヘルです摄取タンパク質をカぜインから大豆タン ハク質に変えることで，各組織，血清，赤血球中の $\alpha$ トコフェロール濃度は影整された。つまり，同じ $\alpha$-ト コフェロール投与レベルではタンパク筫投与レベルの高 いほらか，また，カゼインと大豆タンパク質を比較する

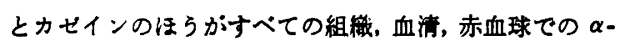

$$
\text { トコフェロールが高かったのである。ビタミン E と撕取 }
$$$$
\text { タンバク筫との鲁および質の影敏については他の研究者 }
$$
はほとんど考虑していない。われわれは，同様にビタ ミ ン E久乏の進行時にも同様な結果を得ている ンバク筫の影零については，機構的には解明されていな いが，一つは肝满でのリボタンパク頎の生合成と分泌に 絡んでいるのではないかと推定しているかいまた証明さ れていない。

\section{4. 他のビタミンなどとの相互関保}

ビタミンEと in vitro で相互作用をむつことが知られ ているビタミンとしてはまず第一にビタミンCがあげら れる。たとえば，均一浴媒系やリボソーム膜および食品 などのin vitroの系ではこのようなビタミンののビタミ 
Table 5. a-Tocopherol concentration in plasma, erythrocytes and tissues after 6 weeks vitamin E deficiency (Exp. 1).

\begin{tabular}{lccc}
\hline & & Group & \\
\cline { 2 - 4 } & C150-DE & C300-DE & C600-DE \\
\hline Dietary AsA $(\mathrm{mg} / \mathrm{kg}$ diet $)$ & 150 & 300 & 600 \\
Plasma $(\mu \mathrm{g} / \mathrm{ml})$ & $2.69 \pm 0.41$ & $0.97 \pm 0.05$ & $0.73 \pm 0.11 \mathrm{a}$ \\
RBC $(\mu \mathrm{g} / \mathrm{ml})$ & $4.15 \pm 0.90$ & $1.39 \pm 0.29$ & $1.12 \pm 0.15^{\mathrm{b}}$ \\
Heart $(\mu \mathrm{g} / \mathrm{g})$ & $20.89 \pm 1.07$ & $14.13 \pm 0.60$ & $15.62 \pm 0.35^{\mathrm{a}}$ \\
Liver $(\mu \mathrm{g} / \mathrm{g})$ & $15.25 \pm 0.28$ & $7.10 \pm 0.31$ & $8.14 \pm 0.27^{\mathrm{a}}$ \\
Kidney $(\mu \mathrm{g} / \mathrm{g})$ & $11.06 \pm 0.88$ & $5.62 \pm 0.38$ & $5.85 \pm 0.22$ \\
Spleen $(\mu \mathrm{g} / \mathrm{g})$ & $25.35 \pm 1.79$ & $10.46 \pm 0.48$ & $12.18 \pm 0.34^{\mathrm{a}}$ \\
Lung $(\mu \mathrm{g} / \mathrm{g})$ & $21.32 \pm 0.81$ & $12.67 \pm 0.52$ & $13.93 \pm 0.41^{\mathrm{a}}$ \\
\hline \hline
\end{tabular}

Values are means $\pm \mathrm{SD}$. The values sharing a superscript letter in group $\mathrm{C} 600$ are significantly different from group C $300 ; a p<0.005$, $p<0.05$.

ンEK対する相互作用はすでに 証明されている35) -41)。 しかし，生体内においてはこの両ビタミンの間にシネル ギストとしての相互作用が存在するかどらかは実験的に はあまり定かてはない。といらのは、ビタミンCが in vivoで生体内の生体脂質膜系での主要な抗酸化剂である

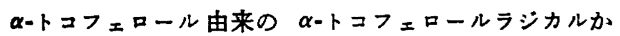
ら $\alpha$-トコフェロールを再生するといったシネルギスト としての作用，あるいはビタミンCがビタミン $\mathrm{E} の$ 消費 を抑制するといった相互作用などが明確に証明されてい ないからである。しかし、この両ビタミンにはなんらか の生体内での相互作用を認めている諭文が多い(42) 50)が， 明瞭ではないるのが大部分である。この理由としては用 いている動物がラントであるため,ピタミンC過剩投与 の踏のビタミンEへの影第を見たるのであったり,ヒト でのデータるそれ活ど有意差は観察されていない。な お，赤血球や血小板などを単唯して in vitroで酸化的な ストレスを与えるとこの両ビタミンの間に相互作用が観 察されているのも事実である。われわれす，この両ビタ ミンの相互作用をビタミンCがビタミン Eの消费の節約 を行らか否かを検討するために，モルモットを使って検 討したがはっきりした結果は得られていなかっだ4)。最 近, Burton らは同様にモ几モ,トでこの両ビタミンの 相互作用を検討しているが，その結果もこのビタミンC にはピタミンEの節約作用がないことを組織中のビタミ ンE搌度から䚀察している51)。われわれはモルモットで このよらにビタミンCがビタミンEに対し, 生体内で節 約作用を示す結果を与えないのは钦物自身に問題がある ためと考え，最近開発されたビタミンCを生合成できな いWistar 系ラット由来の ODS ラットを用いて検討す ることにした。この ODS ラットはアスコルビン酸合成
の最終段階である L-gulonolactone oxidase が久損して いることが知られており，吉田らによればフスコルビン 酸要求量は $300 \mathrm{mg} / \mathrm{kg}$ 飼料で充足されるといわれる ${ }^{76)}$ 。 といらのはモルモットはビタミンEについて組鐡内䈨度 の変動と個体差が大きく，結果の判定に誤差を与えすき るからである。ODS ラットで得られた結果は Table 5, 6 に示すよらにビタミン E久乏の進行中です，通常のレ ヘルのビタミンE投与下においても高レベルのビタミン

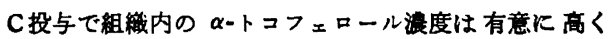

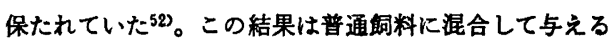
ビタミンE投与法で生体内において，ビタミンEに対し ビタミンCが節約作用を示すことを明確に認めた最初の 論文である。したがって、ビタミンCとビタミンEは多 分生体外と同じような機構で $\alpha$-トコフェロールラジカ

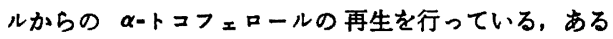
いはビタミンE消费を節約させることにより，組織中の $\alpha$-トコフェロール溜度を高める機能をむつものといえよ 5。

この他のビタミン, 生体成分としては, ビタミンA, ユビキノン,クルタキオンなどの酸化還元系に関与する ビタミン，生体成分などが考えられ，また，リボフラビ ンのようにクルタチオン買元酵素の補酵素として, 脂肪 酸ヒドロベルオキシドの代謝に関係する GSH-px の再 生に開与することを通じて相互作用あるいはなんらかの 関係をるつことが推定されるるのあある。まず,ニビキ ノンについてはラット肝葴を虚血にし，一定時間後に虚 血から回復させるときにあらかじめニビキノンを前投与 しておくことで，ラットの死亡率および肝細胞内での ATP の産生が正常に維持されることが報告されてい

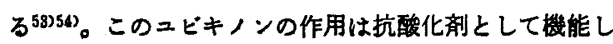


Table 6. $\alpha$-Tocopherol concentration in plasma, erythrocytes and tissues after 6 weeks normal feeding of vitamin E (Exp. 2).

\begin{tabular}{lccc}
\hline & \multicolumn{3}{c}{ Group } \\
\cline { 2 - 4 } & C150-VE & C300-VE & C600-VE \\
\hline Dietary AsA $(\mathrm{mg} / \mathrm{kg}$ diet$)$ & 150 & 300 & 600 \\
Plasma $(\mu \mathrm{g} / \mathrm{ml})$ & $4.80 \pm 0.72$ & $2.32 \pm 0.35$ & $3.37 \pm 0.47 \mathrm{a}$ \\
RBC $(\mu \mathrm{g} / \mathrm{ml})$ & $12.18 \pm 0.62$ & $6.97 \pm 0.75$ & $9.46 \pm 0.59 \mathrm{a}$ \\
Heart $(\mu \mathrm{g} / \mathrm{g})$ & $68.34 \pm 2.72$ & $51.51 \pm 1.85$ & $56.66 \pm 2.41^{\mathrm{a}}$ \\
Liver $(\mu \mathrm{g} / \mathrm{g})$ & $39.99 \pm 3.20$ & $26.33 \pm 1.50$ & $31.54 \pm 2.40^{\mathrm{a}}$ \\
Kidney $(\mu \mathrm{g} / \mathrm{g})$ & $32.16 \pm 2.10$ & $26.55 \pm 1.27$ & $31.08 \pm 1.76^{\mathrm{a}}$ \\
Spleen $(\mu \mathrm{g} / \mathrm{g})$ & $45.25 \pm 3.05$ & $39.65 \pm 0.95$ & $41.91 \pm 1.15^{\mathrm{a}}$ \\
Lung $(\mu \mathrm{g} / \mathrm{g})$ & $70.53 \pm 5.40$ & $54.05 \pm 2.94$ & $62.78 \pm 3.46 \mathrm{a}$ \\
\hline \hline
\end{tabular}

Values are means $\pm S D$. The values sharing a superscript letter in group $\mathrm{C} 600$ are significantly different from group $\mathrm{C} 300 ;$ a $p<0.005$.

ていることが知られているので, ビタミン $\mathrm{E}$ と類似した すのであろ5。事実, 川䛴らはラット肝の虚血時にあら かじめ $\alpha$ トコフェロールを前投与しておくことで, 肝細 胞中の CoQ9 の濃度が有意に増加することを観察してい ろ55。この結果はこの両者の酸化還元作用を通じて, 生 体内でなんらかの相互作用をしている可能性を示するの といえよう。また，この報告では，虚血時における $\alpha$-ト コフェロール前投与による肝クルタチオン濃度への影警 る検討しているか，虚血中のクルタチオンの減少は抑制 できなかったが，血流再開時のグルタチオンの減少は完 全に抑制していた55)。虚血時のこれらのビタミン, 生体 成分の相互作用を図示すれば，Fig. 2 のようである。 最近, 市川らは薬物でグルチオン生合成を低下させた ときにあらかじめビタミン E投与量を高くしておくこと で,クルタチオン生合成阻害による矓臟への毒性が軽减 すると述へている。この結果す先に述べたビタミン Eと クルタチオン両者の生理的な相互作用を示するのといえ よ5 ${ }^{56)}$ 。

次に，必須の锰量元素であるセレンについても，一部 のビタミン いる。この理由としてはセレンが GSH-px の檴成元素 であることに由来することがすでに解明されている。こ れについては，成書あるいは総説を参照されたい57758)。 また，抗酸化性をむつビタミンAについてす古くからビ タミンEとの相互作用が示咬されている59)。しかし, 全 体として正常レヘルル゙のビタミンA摄取状況ではこの両 ビタミンに栄䓹的な観点では相互作用を認めないとする 見解が一般的であり ${ }^{60)}$, しかす最近の研究はきわめて少 ない61。

なお，ビタミン $\mathrm{E}$ 同族体間です相互作用があること

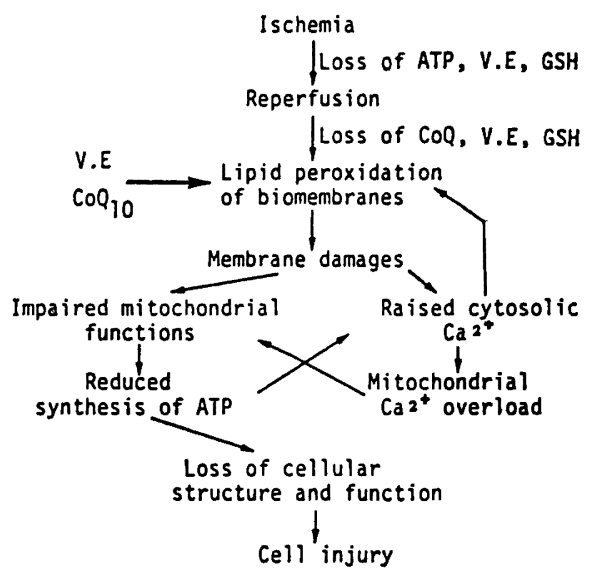

Fig. 2. Schematic representation of the sequence of events leading to ischemic cell injury.

が認められており，食品由来のビタミンEとして重要な $\alpha$-トコフェロールと $\gamma$-トコフェロールの間にす相互作用 が存在することが示されている62)。

\section{5. 日本人の日常におけるビタミンEの掫取状況}

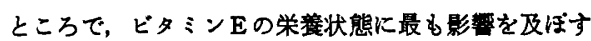
のが, ビタミン $\mathrm{E}$ の摂取量である。

先に，われわれは従来簡易なビタミン $\mathrm{E} の$ 定量法とし て用いられてきた HPLC 法の前処理法に問題点がある

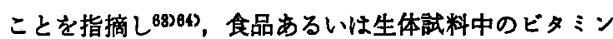
Eのケン化後の抽出溶媒として從来用いられてきたへキ サンでは不十分であり，とくに脂肪分の多い陚料ではへ キサンと酢酸エチルの 9:1 混合容媒がよい成就を与え 
ることを示してきた(53)68)。この方法でないと正確に定量 されないのが生体試料では脂肪組娬と皮店であり，食品 で各桙の畜内製品や魚の加工品などである。この結果 に基つき，今回公表された四訂日本食品標準成分表の フォローフッブロ でビタミンEの分倠定旦法に採用され た方法がわれわれの前処理法である。この方法を用いて 最近の日本人のビタミンE摄取量を推定あるいは実测し よらといら試みが行われた。すなわち，脂溶性ビタミン 総合研究委員会の中で小委員会を作り，そこで，モデル 献立を作成して現在の平均的な日本人のビタミン $\mathrm{E}$ 摂取 量を剆定するとともに，また，今回発表された四訂日本 食品標準成分表のフォローフッブの各食品のビタミン 含量からす計算で求め，実測値と比校した67。その結果 を Table 7 に示す。ここに得られたビタミン $\mathrm{E}$ の摄取 昷についての数值は従来報告されているすのに比べると かなり高くなっている68) -71)。この原因には従来の食事 あるいは献立を用いてビタミンEを定量するときに1日 の食事を作り，全体をミキサーで混合するときに，ビタ ミンEの酸化的な分解についてほとんど考慮が払われて いなかったことも大きな原因といえよう。われわれはは
ほ浐量と考えられるピロガロールを大量に添加すること でビタミンEの混合中および湅結乾燥中の分解を最小限 に防ぐことに成功した。したがって，従来の結果では食 事の前処理中にビタミン $\mathrm{E}$ の損失を招き，結果的にビタ ミンE摄取典を低く見稓もっていたことになったすのと 推定している。

以上われわれの研究室で行ってきたビタミンEに関す

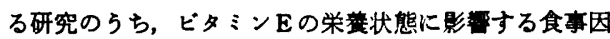
子についておすに述べてきた。われわれはこの他，ビタ ミンEおよび関連化合物の酸化的な分解機構，分解生成 物などについても発表しているか，それらについてはこ の総説では割爱した。文献を参照されたい、72) 75)。終り に，日本栄黄・食糧学会より学会賞を授与され，この総 説を書く機会を与えられたことに対し，厚くお礼申し上 げるとともに，これまでこれらの研究をともに行ってき た研究室の各位に感謝の意を表したい。またこれらの 研究に際して恩師である故 桜井芳人先生ならびに藤巻 正生先生からいたたいた暖かい励ましに心より厚くお札 申し上げます。

Table 7. The tocopherol levels in diets on a week of Kanto area and Kansai area.

(1) Kanto area

\begin{tabular}{|c|c|c|c|c|c|c|}
\hline Day of week & $\alpha$-Toc & $\beta$-Toc & $\gamma$-Toc & $\delta$-Toc & T-Toc & $\alpha$-TE \\
\hline \multicolumn{7}{|l|}{ Husband } \\
\hline Sun. & 9.2 & 1.3 & 24.6 & 4.7 & 39.8 & 10.8 \\
\hline Mon. & 12.4 & 1.6 & 13.0 & 2.7 & 29.7 & 13.4 \\
\hline Tue. & 7.9 & 0.7 & 14.0 & 3.2 & 25.8 & 8.8 \\
\hline Wed. & 11.3 & 1.3 & 5.9 & 0.6 & 19.1 & 11.9 \\
\hline Thu. & 11.0 & 1.3 & 15.1 & 3.3 & 30.7 & 12.1 \\
\hline Fri. & 8.2 & 0.7 & 10.7 & 3.8 & 23.4 & 8.9 \\
\hline Sat. & 9.2 & 0.9 & 13.5 & 3.7 & 27.3 & 10.1 \\
\hline Mean & 9.9 & 1.1 & 13.8 & 3.1 & 28.0 & 10.9 \\
\hline SD (7 days) & 1.7 & 0.4 & 5.6 & 1.3 & 6.5 & 1.7 \\
\hline \multicolumn{7}{|l|}{ Wife } \\
\hline Sun. & 8.5 & 1.2 & 22.4 & 4.3 & 36.4 & 10.0 \\
\hline Mon. & 12.1 & 1.6 & 11.4 & 2.7 & 27.8 & 13.2 \\
\hline Tue. & 7.7 & 0.6 & 14.0 & 3.2 & 25.5 & 8.5 \\
\hline Wed. & 10.1 & 1.1 & 0.9 & 0.0 & 11.6 & 10.4 \\
\hline Thu. & 9.3 & 1.2 & 9.2 & 2.3 & 21.8 & 10.1 \\
\hline Fri. & 8.2 & 0.7 & 10.7 & 3.8 & 23.4 & 8.9 \\
\hline Sat. & 9.1 & 0.8 & 13.5 & 3.7 & 27.7 & 10.8 \\
\hline Mean & 9.3 & 1.0 & 11.7 & 2.9 & 24.9 & 10.3 \\
\hline SD (7 days) & 1.5 & 0.4 & 6.4 & 1.4 & 7.5 & 1.5 \\
\hline
\end{tabular}


(2) Kansai area

(mg/day)

\begin{tabular}{|c|c|c|c|c|c|c|}
\hline Day of week & $\alpha$-Toc & $\beta$-Toc & $r$-Toc & 8-Toc & T-Toc & $\alpha-\mathrm{TE}$ \\
\hline \multicolumn{7}{|l|}{ Husband } \\
\hline Sun. & 11.3 & 0.3 & 10.6 & 2.3 & 24.5 & 10.9 \\
\hline Mon. & 12.5 & 0.5 & 20.8 & 5.6 & 39.4 & 13.6 \\
\hline Tue. & 9.1 & 0.2 & 15.8 & 3.5 & 28.6 & 9.9 \\
\hline Wed. & 6.5 & 0.2 & 9.4 & 4.2 & 20.3 & 7.0 \\
\hline Thu. & 9.0 & 0.3 & 16.1 & 3.4 & 28.8 & 9.9 \\
\hline Fri. & 6.3 & 0.2 & 9.5 & 2.8 & 18.8 & 11.3 \\
\hline Sat. & 8.4 & 0.3 & 13.5 & 3.3 & 25.5 & 9.0 \\
\hline Mean & 9.0 & 0.3 & 13.7 & 3.6 & 26.6 & 10.4 \\
\hline $\mathrm{SD}$ (7 days) & 2.3 & 0.1 & 4.2 & 1.1 & 6.8 & 2.1 \\
\hline \multicolumn{7}{|l|}{ Wife } \\
\hline Sun. & 10.3 & 0.3 & 10.6 & 2.3 & 23.5 & 10.9 \\
\hline Mon. & 12.2 & 0.4 & 19.0 & 5.2 & 36.8 & 13.3 \\
\hline Tue. & 9.2 & 0.3 & 16.2 & 4.1 & 29.8 & 10.0 \\
\hline Wed. & 6.7 & 0.2 & 10.3 & 5.4 & 22.6 & 7.7 \\
\hline Thu. & 9.6 & 0.3 & 16.1 & 4.1 & 30.1 & 10.5 \\
\hline Fri. & 6.8 & 0.2 & 11.2 & 3.9 & 22.1 & 7.4 \\
\hline Sat. & 6.1 & 0.2 & 10.7 & 2.5 & 19.5 & 6.7 \\
\hline Mean & 8.7 & 0.3 & 13.4 & 3.9 & 26.3 & 9.5 \\
\hline SD (7 days) & 2.2 & 0.1 & 3.6 & 1.2 & 6.1 & 2.4 \\
\hline
\end{tabular}

\section{文}

1）五十虫脩：ビタミン E一基碟と臨床一（五十崫修 稨)，22（1985），医歯薬出版（東京）

2) Leth, T. and Sondergaad, H.: J. Nutr., 107, 2236 (1977) ; National Research Council of USA : Recommended Dietary Allowances, 10th Ed., 99 (1989), National Academy Press (Washington)

3）美港，玉井 浩，安田和人，山田智恵子，五 十崖修，林真粧美，平原文子，勝井五一郎，贵島 静正: ビタミン，62，241 (1988)

4) 科学技術庁編：日本食品脂溶珄成分表（脂肪酸， コレステロール, ビタミンE), (1989)

5) Witting, L.A. and Horwitt, M.K. : J. Nutr., 82, 19 (1964)

6) Mouri, K., Ikesu, H. and Igarashi, O. : $J$. Nutr. Sci. Vitaminol., 30, 307 (1984)

7）五十嵐修，毛利佳世，道本千衣子：栄食誌，36, 122 (1983)

8）矨承䤶，小皇義樹，黒田圭一，西出英一，印南 敏 : 栄率誌，42，31 (1984)

9）二木鋭雄：ビタミン $\mathrm{E}$-基喛と臨床一（五十崫修 編)，59 (1985)，医崡薬出版（東京）

10）福沢健治：ビタミン E一基硠と臨床一（五十風修 稨)，77 (1985)，医莯薬出版（東京）

11) McCay, P.B. and King, M.M.: Vitamin E-A Comprehensive Treatise (Machlin, L.J., ed.), 289 (1980), Marcell Dekker (New York)
12）宮沢陽夫：過酸化脂質と生体（内山 充，松尾光 苊, 差䀝井勝編), 98 (1985), 学会出版センター (東京)

13）吉岡稀子, 金田尚志：油化学, 23，321（1974）

14) Tovar, L.R. and Kaneda, T. : Yukagaku, 26, 169 (1977)

15) Iritani, N., Fukuda, E. and Kitamura, Y.: Lipids, 15, 371 (1980)

16) 白台 鸿, 金田尚志: 油化学, 27, 856 (1978)

17) Igarashi, O., Matukawa, H. and Inagaki, C. : J. Nutr. Sci. Vitaminol., 22, 267 (1976)

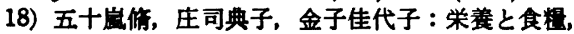
33, 309 (1980)

19) Sagai, M., Ichinose, T., Oda, H. and Kubota, K. : Lipids, 16, 64 (1981)

20) Sagai, M., Ichinose, T., Oda, H. and Kubota, K. : J. Toxicol. Environ. Health, 9, 153 (1982)

21) Bjornson, L.K., Kaydon, H.J., Miller, E. and Moshell, A.N. : J. Lipid Res., 17, 343 (1976)

22) Catignani, G.L. : Biochem. Biophys. Res. Commun., 67, 66 (1975)

23) Caltignani, G.L. and Bieri, J.G. : Biophys. Biochim. Acta, 497, 349 (1977)

24) Mouri, H., Nakagawa, $Y$. , Inoue, $K$. and Nojima, S. : Eur. J. Biochem., 117, 537 (1981)

25）五十峉修，毛利佳世：ビタミン，58，1 (1984)

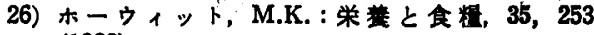
(1982)

27) Horwitt, M.K., Harvey, C.C., Jr. and Reary, 
M.T. : Ann. N.Y. Acad. Sci., 203, 223 (1972)

28) Nishida, Y., Iwakoshi, M., Nakagawa, S. and Mino, M. : J. Nutr. Sci. Vitaminol., 28, 237 (1982)

29) Mino, M., Kitagawa, M. and Nakagawa, S. : Am. J. Clin. Nutr., 41, 631 (1985)

30) 美瀑 真: ビタミン, 61, 433 (1987)

31) Vatassery, G.T., Krezowski, A.M. and Eckfeldt, J.H. : Am. J. Clin. Nutr., 37, 1020 (1983)

32) Mouri, K., Hayafune, Y. and Igarashi, O.: J. Nutr. Sci. Vitaminol., 32, 147 (1986)

33）毛利佳世, 江坂知美, 五十崖伤 : 栄食誌, 37, 441 (1984)

34) Igarashi, O. : Nutritional and Clinical Aspects of Vitamin $\mathrm{E}$ (Hayaishi, $\mathrm{O}$. and Mino, M., eds.), 63 (1987), Elsevier (Amsterdam)

35) Scarpa, M. : Biochim. Biophys. Acta, 801, 215 (1984)

36) Niki, E., Kawakami, A., Yamamoto, Y. and Kamiya, Y. : Bull. Chem. Soc. Jpn., 58, 1971 (1985)

37) McCay, P.B. : Ann. Rev. Nutr., 5, 323 (1985)

38) Niki, E., Saito, T., Kawakami, A. and Kamiya, Y. : J. Biol. Chem., 259, 4177 (1984)

39) Mukai, K. : Biochim. Biophys. Acta, 991, 276 (1987)

40) Niki, E. : Ann. N.Y. Acad. Sci., 498, 186 (1987)

41) Yamauchi, R., Kato, K. and Ueno, Y. : Agric. Biol. Chem., 45, 2855 (1981)

42) Dillard, C.J., Downey, J.E. and Tappel, A.L. : Lipids, 19, 127 (1984)

43) Chen, L.H. and Thacker, R.R. : Int. J. Vitam. Nutr. Res., 56, 253 (1986)

44) Chen, L.H. and Thacker, R.R. : Int. J. Vitam. Nutr. Res., 57, 385 (1987)

45) Kunert, K.J. and Tappel, A.L. : Lipids, 18, 271 (1983)

46) Hruba, F., Novakova, V. and Ginter, E. : Experimentia, 38, 1454 (1982)

47) Bendich, A., D'Apolito, P., Gabriel, E. and Machlin, L.K. : J. Nutr., 114, 1588 (1984)

48) Miyazawa, T., Ando, T. and Kaneda, T. : Agric. Biol. Chem., 50, 71 (1986)

49) Arad, I.D., Dgani, Y. and Eyal, F.G. : Int. J. Vitam. Nutr. Res., 55, 395 (1985)

50) Keith, R.E., Chrisley, B.M. and Driskell, J.A. : Am. J. Clin. Nutr., 33, 2394 (1980)

51) Burton, G.W., Wronska, U., Stone, L., Foster, D.O. and Ingold, K.U. : Lipids, 25, 199 (1990)

52) Igarashi, O., Yonekawa, Y. and FujiyamaFujiwara, Y. : J. Nutr. Sci. Vitaminol., 37, 349 (1991)

53) Marubayashi, S., Dohi, K., Ezaki, H., Yamada, K. and Kawasaki, T. : Surgery, 91, 631 (1982)
54) Marubayashi, S., Dohi, K., Ochi, K. and Kawasaki, T. : Surgery, 99, 184 (1986)

55) Kawasaki, T., Sugino, K., Marubayashi, S., Dohi, K., Ochi, K. and Yamada, K. : Clinical and Nutritional Aspects of Vitamin E (Hayaishi, O. and Mino, M., eds.), 297 (1987), Elsevier (Amsterdam)

56) 获原清和, 津田明子, 市川富夫 : 栄食誌, 42, 377 (1989)

57) 日本ビタミン学会編：ビタミン学 (I)，177 (1980)，東京化学同人（東京）

58）中野稔, 杉岡克昭：ビタミン E一基礎と臨床一

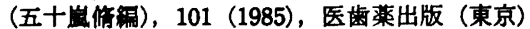

59) Moore, T.: Biochem. J., 34, 1321 (1940)

60) Berger, S. : Bibl. Nutr. Dieta, 15, 85 (1969)

61）紀氏健雄：ビタミン E一基礎と臨床一（五十嵐修 䋧)，177 (1985)，医歯薬出版（東京）

62) Igarashi, O., Hayashi, M. and Chen, M.: Medical, Biochemical Aspects of Free Radicals (Hayaishi, O., Niki, E., Kondo, M. and Yoshikawa, T., eds.), 291 (1989), Elsevier (Amsterdam)

63) Ueda, T. and Igarashi, O.: J. Micronutr. Anal., 1, 31 (1985)

64) Ueda, T. and Igarashi, O.: J. Micronutr. Anal., 3, 15 (1987)

65) Ueda, T. and Igarashi, O.: J. Micronutr. Anal., 3, 185 (1987)

66) Ueda, T. and Igarashi, O. :J. Micronutr. Anal., 7, 79 (1990)

67）平原文子，植田忠彦，西宗高弘，五十嵐脩，美㹸 真:ビタミン, 65, 103 (1991)

68) Fukuba, H. : International Symposium on Vitamin E (Shimazono, N., ed.), 63 (1972), Kyoritu Shuppan Co. (Tokyo)

69）池畑秀夫, 田中東子, 上嶋千鶴子：ビタミン, 38, 253 (1968)

70）井䓫や蒠こ，日高公雄，吉田宏三，戸田和子：栄 食誌, 38, 351 (1985)

71）平原文子，菊池亮也，伊藤洋子，木村修一：国立 栄研報告, 34, 57 (1985)

72) Fujimaki, M., Kanamaru, K., Kurata, T. and Igarashi, O.: Agric. Biol. Chem., 34, 1781 (1970)

73) Igarashi, O. : J. Nutr. Sci. Vitaminol., 23, 169 (1977)

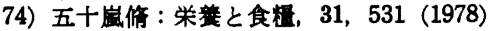

75) $\mathrm{Ha}, \mathrm{K} . \mathrm{H}$. and Igarashi, O.: J. Nutr. Sci. Vitaminol., 36, 411 (1990)

76) Mizushima, Y., Harauchi, T., Yoshizaki, T. and Makino, S. : Experimentia, 40, 359 (1984); Horio, F., Ozaki, K., Yoshida, A., Makino, S. and Hayashi, Y. : J. Nutr., 115, 1630 (1985); 垍尾文彦, 吉田 昭: ピタミン, 62, 317 (1988)

(1991 年 4 月 1 日受理) 